\title{
Prevalensi Penurunan Visus pada Siswa Berkebutuhan Khusus di SLB Kasih Angelia Kota Bitung Tahun Ajaran 2017/2018
}

\author{
1 Junifer M. L. Dalope \\ ${ }^{2}$ Josefien Saerang \\ ${ }^{2}$ Vera Sumual
}

\author{
${ }^{1}$ Program Studi Pendidikan Dokter Fakultas Kedokteran Universitas Sam Ratulangi Manado \\ ${ }^{2}$ Bagian Ilmu Kesehatan Mata Fakultas Kedokteran Universitas Sam Ratulangi Manado \\ Email: dalopejunifer@gmail.com
}

\begin{abstract}
Untreated visual disorder can result in mild to severe visual problems, and even blindness. This study was aimed to determine the prevalence of decreased visus in students with special needs in SLB Kasih Angelia Bitung of academic year 2017/2018. This was a descriptive prospective study. There were 61 students with special needs in this study. Of the total 61 students, 29 students had decreased vision and 32 students had normal visus. Refractive anomaly cases were higher in males versus females, and dominated by age group of 16-20 years. The prevalences of hypermetropia, astigmatism, myopia, and multiple refractive anomalies disorders were 31\% (9 students), 27.6\% (8 students), 20.7\% (6 students), 20.7\% (6 students) respectively. Conclusion: Decreased visus due to refractive anomalies were more prevalent in male students, age group of 16-20 years, and in students with deaf disability. Hypermetropia was the most common type of refractive anomalies.
\end{abstract}

Keywords: decreased vision, refractive anomaly

\begin{abstract}
Abstrak: Gangguan penglihatan yang tidak dikoreksi dapat mengarah kelainan visus ringan sampai berat, bahkan sampai mengalami kebutaan. Penelitian ini bertujuan untuk mengetahui prevalensi penurunan visus pada siswa berkebutuhan khusus di SLB Kasih Angelia Kota Bitung tahun ajaran 2017/2018. Jenis penelitian ialah deskriptif prospektif. Terdapat 61 siswa berkebutuhan khusus dalam penelitian ini. Di antaranya terdapat 29 siswa yang mengalami penurunan visus (kelainan refraksi) dan 32 siswa lainnya memiliki visus normal. Kelainan refraksi lebih banyak ditemukan pada laki-laki dibandingkan perempuan dan didominasi oleh kelompok usia 16-20 tahun. Prevalensi hipermetropia, astigmatisma, miopia, dan kelainan refraksi ganda secara berturut-turut ialah 31\% (9 siswa), 27,6\% (8 siswa), 20,7\% (6 siswa), dan 20,7\% (6 siswa). Simpulan: Penurunan visus seperti kelainan refraksi lebih banyak didapatkan pada siswa laki-laki, kelompok usia 16-20 tahun, dan pada jenis kecacatan tunarungu. Hipermetropia merupakan jenis kelainan refraksi yang paling banyak ditemukan.
\end{abstract}

Kata kunci: penurunan visus, kelainan refraksi

Mata merupakan indera penglihatan yang dimiliki manusia. Melalui mata manusia menyerap informasi visual yang digunakan untuk melaksanakan berbagai kegiatan. Namun gangguan terhadap penglihatan banyak terjadi, mulai dari gangguan ringan hingga gangguan berat yang dapat mengakibatkan kebutaan. ${ }^{1}$ Gangguan tajam penglihatan ini merupakan masalah pada masyarakat yang akan dijumpai selama tidak didapati adanya tindakan preventif sejak dini. ${ }^{2}$

Sesuai data global gangguan penglihatan 2010 yang diterbitkan WHO, diprediksi terdapat 285 juta orang yang mengalami gangguan penglihatan di seluruh dunia dimana saat itu jumlah penduduk dunia mencapai 6.69 milyar jiwa, persentasi 
gangguan penglihatan global yaitu $4,25 \%$. Dari 285 juta orang tersebut, 39 juta $(0,58 \%)$ di antaranya mengalami kebutaan menurut kategori ICD-10.,

Berdasarkan Riset Kesehatan Dasar (RISKESDAS) 2013, prevalensi severe low vision penduduk umur 6 tahun ke atas secara nasional sebesar $0,9 \%$. Prevalensi severe low vision tertinggi terdapat di Lampung (1,7\%), diikuti Nusa Tenggara Timur dan Kalimantan Barat (masingmasing 1,6\%). Provinsi dengan prevalensi severe low vision terendah adalah DI Yogyakarta $(0,3 \%)$ diikuti oleh Papua Barat dan Papua (masing-masing 0,4\%).

Di Sulawesi Utara sendiri penduduk untuk usia $\geq 5$ tahun berjumlah 2.145.064 orang, dengan prevalensi severe low vision mencapai $0,9 \%$ atau sekitar 19.306 orang. Provinsi Sulawesi Utara menempati urutan ke tiga kebutaan di Indonesia yaitu sebesar $0,8 \%$ dari total populasi. ${ }^{3,4}$

Gangguan penglihatan merupakan masalah kesehatan yang penting, terutama pada anak, mengingat $80 \%$ informasi selama 12 tahun pertama kehidupan anak di dapat melalui penglihatan. Sama halnya dengan orang normal, pada siswa berkebutuhan khusus atau penyandang disabilitas yang memiliki gangguan ketajaman penglihatan biasanya di sebabkan oleh adanya gangguan sejak masih dalam kandungan atau didapat setelah kelahiran maupun disebabkan oleh adanya kelainan refraksi karena faktor eksternal. ${ }^{5,6}$

Penelitian ini bertujuan untuk mengetahui penurunan visus pada siswa berkebutuhan khusus di SLB Kasih Angelia Kota Bitung pada tahun ajaran 2017/2018. Diharapkan hasil penelitian ini dapat menambah informasi mengenai penurunan visus dan digunakan sebagai sumber untuk penelitian yang lebih lanjut.

\section{METODE PENELITIAN}

Jenis penelitian ini ialah deskriptif prospektif dengan mengukur langsung visus dari siswa berkebutuhan khusus di
SLB Kasih Angelia Kota Bitung tahun ajaran 2017/2018. Variabel penelitian ialah jenis kelainan refraksi, jenis kecacatan, usia, dan jenis kelamin.

\section{HASIL PENELITIAN}

Tabel 1 menunjukkan bahwa angka kejadian visus normal pada siswa berkebutuhan khusus di SLB Kasih Angelia Kota Bitung lebih tinggi dibandingkan dengan angka kajadian penurunan visus atau adanya kelainan refraksi. Siswa dengan jenis kelamin laki-laki lebih banyak memiliki visus normal yaitu 27 siswa (60\%). Yang mengalami penurunan visus pada siswa dengan jenis kelamin laki-laki yaitu 18 siswa (40\%) dari total jumlah siswa laki-laki.

Berbeda halnya dengan siswa dengan jenis kelamin laki-laki, pada siswa dengan jenis kelamin perempuan yang memiliki penurunan visus lebih tinggi dibandingkan dengan siswa yang memiliki visus normal yaitu sebanyak 11 siswa $(68,8 \%)$ sedangkan siswa dengan visus normal sebanyak 5 siswa $(31,2 \%)$.

Tabel 1. Distribusi penurunan visus dan visus normal berdasarkan kelamin $(n=61)$

\begin{tabular}{ccc}
\hline $\begin{array}{c}\text { Jenis } \\
\text { kelamin }\end{array}$ & $\begin{array}{c}\text { Visus } \\
\text { normal }\end{array}$ & $\begin{array}{c}\text { Penurunan } \\
\text { visus }\end{array}$ \\
\hline Laki-laki & 27 & 18 \\
Perempuan & 5 & 11 \\
Total & 32 & 29 \\
\hline
\end{tabular}

Tabel 2 memperlihatkan bahwa kelainan refraksi paling banyak dialami oleh siswa laki-laki dibandingkan perempuan. Hipermetropia merupakan jenis kelainan refraksi dengan prevalensi tertinggi dibandingkan kelainan refraksi lainnya yakni $31,03 \%$ dari jumlah sampel dengan kelainan refraksi. Jenis kelainan refraksi terendah ialah kelainan refraksi ganda yaitu hipermetropia astigmatisma sebanyak $6,9 \%$ dari jumah sampel. 
Tabel 2. Distribusi kelainan refrakasi berdasarkan Jenis kelamin $(n=61)$

\begin{tabular}{ccccccc}
\hline $\begin{array}{c}\text { Jenis } \\
\text { kelamin }\end{array}$ & Hipermetropia & Miopia & Astigmatisma & HA & MA & Normal \\
\hline Laki-laki & 7 & 4 & 4 & 1 & 2 & 27 \\
Perempuan & 2 & 3 & 4 & 1 & 2 & 5 \\
Total & 9 & 7 & 8 & 2 & 4 & 32 \\
\hline
\end{tabular}

Ket: HA , Hipermetropia Astigmatisma; MA, Miopia Astigmatisma

Dari Tabel 3 didapatkan variasi usia dari tiap jenis kelainan refraksi. Secara keseluruhan kelompok usia 16-20 tahun memiliki prevalensi tertinggi yang mengalami kelainan refraksi yaitu 13 siswa $(44,8 \%)$. Kelompok usia dengan prevalensi terendah yaitu kelompok usia $\geq 26$ tahun sebanyak 1 siswa $(3,4 \%)$. Pada usia 21-25 tahun tidak terdapat kelainan refraksi.

Tabel 3. Distribusi kelainan refraksi berdasarkan usia $(n=61)$

\begin{tabular}{ccc}
\hline $\begin{array}{c}\text { Usia } \\
\text { (tahun) }\end{array}$ & Frekuensi & $\begin{array}{c}\text { Persentase } \\
(\%)\end{array}$ \\
\hline $6-10$ & 3 & $10,4 \%$ \\
$11-15$ & 12 & $41,4 \%$ \\
$16-20$ & 13 & $44,8 \%$ \\
$21-25$ & 0 & $0 \%$ \\
$\geq 26$ & 1 & $3,4 \%$ \\
Total & 29 & $100 \%$ \\
\hline
\end{tabular}

Tabel 4. Distribusi kelainan refraksi berdasarkan jenis kecacatan $(n=61)$

\begin{tabular}{ccc}
\hline Jenis kecacatan & Frekuensi & $\begin{array}{c}\text { Persentase } \\
(\boldsymbol{\%})\end{array}$ \\
\hline Tunarungu & 12 & $41,4 \%$ \\
Tunagrahita & 6 & $20,7 \%$ \\
Tunadaksa & 2 & $6,9 \%$ \\
Tunalaras & 2 & $6,9 \%$ \\
GPPH & 1 & $3,4 \%$ \\
Autisme & 5 & $17,3 \%$ \\
Down syndrome & 1 & $3,4 \%$ \\
Total & 29 & $100 \%$ \\
\hline
\end{tabular}

Tabel 4 menunjukkan bahwa jumlah penurunan visus tertinggi yaitu pada jenis kecacatan tunarungu sebesar 12 siswa $(41,37 \%)$, diikuti dengan jenis kecacatan tunagrahita sebanyak 6 siswa $(20,68 \%)$. Jenis kecacatan GPPH dan Down syndrome memiliki penurunan visus yang paling sedikit yakni 1 siswa $(3,44 \%)$ dari total penurunan visus untuk masing-masing jenis kecacatan.

\section{BAHASAN}

Berdasarkan penelitian yang dilakukan di SMAN 7 Manado dan penelitian di Khasmir India, didapatkan persentase tertinggi dari kelainan refraksi yaitu miopia jika dibandingkan dengan kelainan refraksi lain. ${ }^{7-9}$ Berbeda halnya dengan penelitian ini yang dilakukan pada siswa berkebutuhan khusus di SLB Kasih Angelia Kota Bitung didapatkan prevalensi tertinggi pada kelainan refraksi ialah hipermetropia; hal ini disebabkan pada siswa berkebutuhan khusus bola mata anteroposterior yang terbentuk terlalu pendek dan kekuatan refraksi terlalu lemah, bentuk anatomi mata pada siswa berkebutuhan khusus mengalami abnormalitas, atau terdapat penyakit mata tertentu dan trauma. ${ }^{10}$

Berdasarkan jenis kelamin perempuan lebih banyak mengalami kelainan refraksi dibandingkan laki-laki. Hal ini sesuai dengan hasil penelitian National Institute of Eye Health ${ }^{11}$ yang menyatakan perempuan lebih banyak mengalami kelainan refraksi dibandingkan laki-laki. Seperti halnya penelitian yang dilakukan Kalagi et al. ${ }^{12}$ di RSUP Prof. R. D. Kandou tahun 2016 menyatakan bahwa perempuan lebih banyak didiagnosis memilki kelainan refraksi dibandingkan laki-laki. Hasil penelitian di atas tidak sejalan dengan penelitian ini yang mendapatkan prevalensi tertinggi kelainan refraksi pada jenis kelamin laki-laki (62\%) dibandingkan perempuan (38\%). Hal ini disebabkan karena jumlah responden laki-laki pada 
penelitian ini lebih banyak dibandingkan jumlah responden perempuan.

Berdasarkan usia, kelompok usia 16-20 tahun memiliki prevalensi kelainan refraksi tertinggi dibandingkan usia lain. Hal ini sesuai dengan penelitian yang dilakukan oleh Jasbeen et al. di Kashmir India yang menyatakan bahwa usia remaja 13-16 tahun dan usia muda $\geq 17$ tahun memiliki kelainan refraksi yang tinggi. ${ }^{8}$ Hal ini disebabkan karena pada usia tersebut lebih sering mengalami kelainan refraksi yang disebabkan karena aktivitas yang memperberat faktor-faktor risiko terjadinya kelainan refraksi seperti aktivitas membaca di tempat yang memiliki cahaya yang tidak memadai, aktivitas bermain game, bekerja di depan laptop atau komputer dengan jarak pandang yang dekat terhadap monitor, dan terlalu lama terpapar dengan gadget. ${ }^{8,13}$

Berdasarkan jenis kecacatan yang memiliki prevalensi tertinggi terhadap kelainan refraksi yaitu jenis kecacatan tunarungu $(41,37 \%)$ diikuti oleh jenis kecacatan tuna grahita $(20,7 \%)$ dan terendah oleh jenis kecacatan GPPH dan Down syndrome $(3,4 \%$ untuk setiap jenis kecacatan). Prevalensi kelainan refraksi tertinggi pada tunarungu disebabkan karena responden pada penelitian ini sebagian besar dari jenis kecacatan tunarungu. Selain jumlah responden kecacatan ini yang lebih banyak dari jumlah responden yang lain, terdapat faktor-faktor risiko seperti bermain gadget terlalu sering dan terlalu banyak terpapar dengan hal-hal yang memperberat faktor risiko menyebabkan siswa dengan jenis kecacatan tunarungu lebih tinggi dalam hal kelainan refraksi dibandingkan dengan jenis kecacatan yang lain.

Pada siswa dengan hipermetropia kelompok usia dengan kasus terbanyak ialah kelompok usia 16-25 tahun yaitu sebanyak 5 siswa $(55,55 \%)$ dari total kasus hipermetropia dengan 7 kasus pada lakilaki dan 2 kasus pada perempuan. Hal ini sesuai dengan penelitian yang dilakukan di Mö̈bius di Brazil yang menunjukan hasil hipermetropia termasuk kelainan refraksi yang banyak terjadi. ${ }^{14}$ Kasus hipermetropia lebih banyak dialami oleh perempuan yakni
750 kasus atau 59,1\% dari jumlah kasus hipermetropia menurut studi global yang dilakukan di Mediterania Spanyol oleh Gracia-Lazaro. ${ }^{14}$ Berbagai studi global menunjukkan bahwa hipermetropia sering terjadi pada anak-anak dan orang tua serta menurun pada dewasa muda. ${ }^{15}$ Namun pada penelitian ini jumlah responden dengan usia dewasa muda lebih banyak sehingga lebih banyak hasil yang menunjukan adanya hipermetropia. Penelitian di RSUP Prof. R. D. Kandou mendapatkan usia $\geq 17$ tahun dengan hipermetropia jarang memberikan keluhan karena matanya masih mampu melakukan akomodasi kuat untuk melihat benda dengan jelas. Hal ini yang menyebabkan kurangnya pasien muda yang datang melakukan pemeriksaan dan didiagnosis hipermetropia. ${ }^{12}$

Pada penelitian ini didapatkan 6 kasus miopia dengan jenis kecacatan tunarungu, tunagrahita, autis, tunadaksa, dan tunalaras. Prevalensi kejadian miopia pada kasus ini tertinggi pada kelompok usia 16-20 (66,7\%), diikuti kelompok usia 11-15 tahun $(33,3 \%)$. Hal ini sesuai dengan berbagai studi miopia diantaranya Visual Impairment Project, Baltimore Eye Survey, dan Beaver Dam Eye Study yang melaporkan prevalensi miopia lebih tinggi pada orang dewasa muda dan mengalami penurunan pada kelompok usia lebih tua atau $>65$ tahun. Pada penelitian di Amerika Serikat yang membedakan kelainan refraksi berdasarkan jenis kalamin didapatkan bahwa semua ras dengan jenis kelamin perempuan lebih tinggi dibandingkan laki-laki yakni perempuan sebanyak 75.147.949 kasus (55\%) sedangkan laki-laki $\quad 67.500 .444$ kasus $(45 \%) .{ }^{16}$ Namun pada penelitian ini yang dilakukan di SLB, jenis kelamin lakilaki lebih banyak mengalami miopia dibandingkan dengan perempuan karena responden laki-laki lebih banyak $(66,7 \%)$ daripada perempuan $(33,3 \%)$.

Angka kejadian astigmatisma pada penelitian ini ialah kedua tertinggi setelah hipermetropia yaitu 27,59\% dari total kasus kelainan refraksi. Pada kasus astigmatisma jenis kecacatan yang memiliki astigmatisma ialah tunarungu (25\%), tunagrahita 
(25\%), autis (25\%), GPPH (12.5\%), dan Down syndrome (12,5\%). Pada kasus astigmatisma didapatkan bahwa kelompok usia 11-15 tahun dan kelompok usia 16-20 tahun merupakan kelompok usia terbanyak yaitu untuk masing-masing kelompok usia sebesar $37,5 \%$ dari total kasus astigmatisma, disusul oleh kelompok usia 6-10 tahun sebesar $25 \%$ dari total kelainan refraksi astigmatisma. Astigmatisma paling banyak didapatkan pada bayi dan orang dewasa. ${ }^{17}$ Berdasarkan jenis kelamin kasus astigmatisma lebih banyak didapatkan pada jenis kelamin perempuan dibandingkan lakilaki. $^{18}$ Pada penelitian ini prevalensi kejadian astigmatisma sama antara laki-laki dan perempuan (masing-masing sebesar $50 \%$ ). Astigmatisma biasanya didapatka secara herediter dan muncul saat lahir namun dapat menurun atau bertambah buruk seiring bertambahnya usia. Astigmatisma juga bisa muncul akibat trauma ataupun operasi pada mata. ${ }^{12,18}$

\section{SIMPULAN}

Dari hasil penelitian dapat disimpulkan bahwa hampir 50\% dari responden yang dilakukan pengukuran visus mengalami kelainan refraksi; sebagian dengan kelainan refraksi ganda. Kasus kelainan refraksi tertinggi didapatkan pada jenis kelamin laki-laki dan kelompok usia 16-20 tahun. Prevalensi hipermetropia yang tertinggi dibandingkan jenis kelainan refraksi lainnya dan yang terendah ialah jenis kelainan refraksi ganda hipermetropia dan astigmatisma . Jenis kecacatan paling tinggi terhadap kelainan refraksi ialah tunarungu.

\section{SARAN}

Orang tua siswa diharapkan dapat meningkatkan kepedulian tentang pentingnya fungsi penglihatan dengan memperhatikan faktor-faktor risiko yang dapat menyebabkan gangguan penglihatan.

Disarankan unuk melakukan penelitian lebih lanjut tentang data visus kelainan refraksi secara keseluruhan dan penelitian lebih lanjut tentang faktor-faktor risiko terjadinya kelainan refraksi.

\section{UCAPAN TERIMA KASIH}

Ucapan terima kasih ditujukan kepada seluruh siswa dan guru SLB Kasih Agelia Kota Bitung atas partisipasinya dan Staf refraksionis Bagian Ilmu Kesehatan Mata atas bantuan dan kerja samanya serta pihak lain yang terlibat dalam penyelesaian penelitian ini.

\section{DAFTAR PUSTAKA}

1. Pusat Data dan Informasi Kementerian Kesehatan RI. Situasi Gangguan penglihatan dan kebutaan. 9 Oktober 2014 [cited 2017 Aug 17]. Available from: http://www.depkes.go.id/ download.php?file=download/pusdatin/ infodatin/infodatin-penglihatan.pdf

2. Juneti, Bebasari E, Nukman E. Gambaran faktor-faktor yang mempengaruhi gangguan tajam penglihatan pada anak sekolah dasar kelas V dan kelas VI di SDN 017 Bukit Raya Pekan Baru tahun 2014. JOM FK UNRI. 2015;2(2):3.

3. Badan Penelitian dan Pengembangan Kesehatan Kementrian RI. Riset kesehatan dasar 2013. 2013 [diakses 23

Agu 2017]. Tersedia dari: http://www.depkes.go.id/resources/dow nload/general/Hasil\%20Riskesdas\%20 2013.pdf

4. Badan Penelitian dan Pengembangan Kesehatan Kementrian Kesehatan RI. Penyajian pokok-pokok hasil riset kesehatan dasar 2013. 2013 [diakses 23 Agu 2017]. Tersedia dari : http://www.who.int/blindness/AP2014_ 19_English.pdf?ua=1

5. Mangunsong F. Psikologi dan Pendidikan Anak berkebutuhan Khusus Jilid 1 . Jakarta: LPSP3UI, 2009; p. 153-60.

6. Hartono. Simptomatologi dalam NeuroOftamologi. Jakarta: FKUI. p.12-15

7. Adile A, Tongku Y, Rares LM. Kelainan refraksi pada pelajar SMA Negeri 7 Manado. e-Cl. 2016;4(1):24

8. Ishfaq A, Seema M, Andrabi KI, et al. Prevalence of myopia in students of Srinagar City of Khasmir, India. Int J Health Sci (Qassim). 2008;2(1):77-81.

9. William KM,Verhoeven VJ, Cumberland P, Bertelsen G, Wolfram C, Buitendijk GH, et al. Prevalence of refractive error in Europe: the European Eye Epidemiology (E(3)) Consortium. Eur J 
Dalope, Saerang, Sumual: Prevalensi penurunan visus pada siswa berkebutuhan khusus ...

Epidemiol. 2015;30(4):305-15.

10. Ilyas HS. Ilmu Penyakit Mata (3rd ed). Jakarta: Balai Penerbit FKUI, 2009; p. 44-7, 64-8.

11. National Institute of Health. Fact Sheet: refractive errors. 2016 [cited 2018 nov 5]. Available from: https://nei.nih.gov /sites/default/files/health-pdfs/ HVM09_Fact_Sheet_tagged.pdf

12. Kalangi W, Rares L, Sumual V. Kelainan refraksi di poliklinik mata RSUP Prof. Dr. R. D. Kandou Manado periode Juli 2014-Juli 2016. JKK. 2016;1(01):85-9.

13. Giri KGB, Dharmadi M. Gambaran ketajaman penglihatan berdasarkan intensitas bermain game siswa laki-laki Sekolah Menengah Pertama di wilayah kerja Puskesmas Gianyar I bulan Maret-April 2013. E-journal Medika Udayana. 2015;4(1):3-7.

14. Garcia LS. Prevalemcia refractive en una pooblaction mediteeanea espanola. Gac Optica. 2010;448:34-8

15. Romin DM, Taboada JJ, Montes P, Anguila A, Martinez N. Global prevalence of hyperopia. J Emmetropia. 2015;6:109-16.

16. Prevent Blindness America. Myopia prevalence by gender. 2012 [cited 2016 Nov 5]. Available from: http://www. visionproblemsus.org/refractiveerror/myopia/myopia-by-gender.html

17. Vitale S, Ellwein L, Cotch MF. Prevalence of refractive error in the United States, 1999-2004. Arch Ophthalmol. 2008; 126:1111-9.

18. American Optometric Association Astigmatism. 2016 [cited 2017 Nov 5]. Available from: http://www.aoa.org/ patients-and-public/eye-and-visionproblems/glossary-of-eye-and-visionconditions/astigmatism?sso=y 